\title{
Ssciendo
}

Ethics \& Bioethics (in Central Europe), 2020, 10 (3-4), 116-132

DOI:10.2478/ebce-2020-0017

\section{Virtual reality and imagination - a possible ethical framework based on the thought of Gregory of Nazianzus}

\author{
Václav Ježek ${ }^{1}$
}

\begin{abstract}
The present article discusses the thoughts of Gregory of Nazianzus in relation to virtual reality especially manmade virtual reality in all its forms. We argue that the benefits of virtual reality, such as freedom, imagination, creativity can be paradoxically curtailed by virtual reality itself, since it is highly subjective and as its medium shows, can be an a priori matrix and prison for the human being. Gregory of Nazianzus, building his theology on a firm basis on substance and contemplation, offers a way out, where one acknowledges everything around us as beneficial and beautiful and therefore free, but this must be based on a firm grounding of truthfulness and guidance offered by an all-encompassing form of Divine love and creativity.
\end{abstract}

Keywords: Gregory of Nazianzus, virtual reality, imagination, internet, ethics

\section{Introduction}

The expansion of Virtual reality in all walks of life presents clear challenges which incorporate ethical issues. Technology is being developed so rapidly that possible ethical frameworks relating to it are lagging. Furthermore, given the state of ethics in terms of virtual reality one clearly observes a certain quandary how to identify the basic negative or positive elements present in virtual reality. While the debate is extensive, the pillars of a possible ethics of virtual reality are neither stable nor developed.

Virtual reality (and its other forms such as the internet, etc.) is based on imagery, design, and cognitive perceptions of reality (or their absence). Some scholars such as Brey called the process of integrating morality and ethics into design as "Anticipatory technology ethics" (Brey, 2011, p. 13).

One of the striking issues in virtual reality is its possible effect on desensitisation. Virtual reality has a link to sensitivity and to the development of our overall human psychological framework. This is further linked with the element of "control" which is obviously exercised by the creator of virtual reality. Virtual reality offers a "closed" world. Recently, many articles discuss the possibilities of virtual reality in cognitive therapy (Reppetto \& Riva, 2011). However, virtual reality can limit the freedom, objectivity and psychosomatic development of the human being, especially sense perception and other related categories.

In our present discussion, we try to develop a framework for an ethics of virtual reality based on the thoughts of Gregory of Nazianzus. What can Gregory offer? In his works, Gregory meditates on the negative and positive features of images around us, whether we call them reality or virtual reality. He believes that our happiness is limited by the fact that we limit our world to our own subjective imagery and design, similarly to the person who creates his or her own virtual reality. We cannot simply trust anything around us unless we realise its origin and meaning. Our perception is or can be distorted creating a problem for our psychosomatic development. Whether one is a theist or not, Gregory's exposé of the image and its relationship to reality can offer much needed insight into the positives and negatives of virtual reality.

The present contribution is an assessment of some aspects of the thoughts of Gregory of Nazianzus in relation to the phenomenon of virtual reality. We discuss forms of virtual reality in relation to the internet, social media, and other forms, where virtual reality provides a platform. Of course, it is important to clarify what one understands as virtual reality. As has

\footnotetext{
${ }^{1}$ University of Prešov (Slovakia); vaclavjezek111@gmail.com
} 
been observed by many scholars, even physical reality in terms of its apparent indeterminacy can provide a form of virtual reality. As shown by Whitworth for example, physics and its theories often provide models of reality including physical laws, which on their own seem to be so incomprehensible for the human mind that they seem to be a form of virtual reality (Whitworth, 2007, p. 319). This obviously requires one to clarify what we understand as virtual reality. The point here is to establish what kind of laws if any govern reality or virtual reality. Without laws we may argue any reality is devoid of substance. Some commentators have expressed their ideas about the necessity of identifying markers of reality. Without reality one may end up in unreality, which is not possible. For a discussion on this idea of an ontology of reality (Gilyazova, 2019).

Given these observations, Gregory of Nazianzus can help us here. For the patristic tradition or for Gregory there is no possibility of losing one's identity in any form of reality. Why? Because all reality is based on God and the Divine, which grounds all existence. This kind of luxury of thought is not available to the non-theist philosopher, who has, to come up with such a definition of reality or virtual reality as to make sense of the "senseless movements" of images, which seem to entrap us in a world of purposelessness and therefore unhappiness. This is the danger of virtual reality itself, that it propels one into a void of moving images, where laws are structured in such a way as not to offer any standing ground for a taxonomy of reality and therefore truth or life. Here images are, of course, not pictures but all physicality and mental imagery. By defining image, substance, the Divine and other issues, Gregory provides us with a solid framework for understanding reality and, by extension, virtual reality. Virtual reality of course, is not a new concept and has been present in history in one way or another for 3000 years.

The central thesis of our article is a new avenue of exploration, which we have developed along the lines of Gregory of Nazianzus. This exploration has been developed as an answer to some issues of virtual reality. We ask ourselves whether virtual reality and its various platforms (internet, social media etc.), is not a challenge to reality itself. Whether virtual reality is a delusion or illusion which moves us further away from reality and therefore from happiness and truth. If reality is itself a "painful" concept is it perhaps not the case that virtual reality is even more dangerous?

We further ask ourselves whether in fact the often stressed and presented benefits of virtual reality such as the development of imagination, development of communication etc., are not illusionary. Whether in fact virtual reality is a hindrance to personal relationships. Gregory of Nazianzus, an author from the fourth century AD can provide some answers.

The thoughts of Nazianzus are corroborated by contemporary thinkers in many ways. Poincaré for example, similarly to Christian thinking emphasised that science at the same time moves to complexity and variety but also to simplicity and oneness (Poincaré, 1917, pp. 202203). Similarly, Poincare believed that mathematical thought cannot be independent of the mind. In theological terms, a construction of an entity or form could mean its artificial projection and a construction of a substance, which however will always be purely subjective. Some forms of intuitive philosophy attempted to address these issues such as the thoughts of Nikolay Lossky and by other authors.

\section{How do we discern substances or objects?}

The physicality of reality necessarily must indicate that our perception is based on "real and objective" perception and observation as far as the mental cognitive faculties of the human being are capable. Whether we are capable or not of perceiving the physicality of reality, bodies and causal relationships are a given fact in the world around us. There is a substance (agreeing here with the primeval definitions of Aristotle) that can have a form and to this extent is an 
"object of reflection". The emphasis on matter and form is an important aspect of Aristotle in this context.

The Fathers of the Church such as Gregory in comparison to other schools of thought in his period would never deny the physicality or matter or bodily form of things and beings. The basis of the controversies surrounding Christ would often touch on the bodily reality of Christ. The strong affirmation that one cannot be saved unless Christ did in reality assume our bodily nature with all its characteristics is a given fact in Fathers such as Gregory. This is often underappreciated in modern reflections because the conclusions of this view are often left unexpanded. The emphasis on corporality undoubtedly set these "realist" Fathers apart from the extreme spiritual (gnostic) schools surrounding them.

What needs to be emphasised from the outset is the fact that, given this line of reasoning, Gregory would never deny the "objectiveness" of reality. Gregory does not need to escape to forms of matter- less spiritualism to prove the truthfulness of his anthropology. For him there is "reality" a "substantial" existence. Existence and substance are linked here, since without an expression into "existence" one would not know that there was or is a "substance". In this regard, in terms of Divinity, there is a perfect correspondence between existence and substance, since how God exists, or acts is a perfect reflection or correspondence with his substance.

Gregory generally stresses the fact that God is not a composite being. This is very important. If God is "simple" this does not mean that Gregory is subscribing to some non-personal forms of God, but he is pointing to the very important fact that there is no object in creation that can fully circumscribe God. Therefore, any form of analogy is doomed to failure. It can only serve a pedagogical purpose. Even a comparison is inadequate. Thus, in his Fifth Theological Oration he observes: "I have very carefully considered this matter in in my own mind, and have looked at it in every point of view, in order to find some illustration of this most important subject, but I have been unable to discover anything on earth with which to compare the nature of the Godhead" (Or. 31(5), 31, 1-4). ${ }^{2}$ Gregory is perfectly aware that any object or, in fact, image is in danger of "delusion" or "illusion". Obviously the "simple" nature of God is paradoxically a reflection of his superior complexity which is incomprehensible for anything outside God.

The substance according to the Patristic understanding of virtue being Divine and full of love is not a substance which is without activity. An especially important passage in Gregory stresses the unique nature of God who even before creation was full of activity contemplating his own self, by reference to beauty. Gregory observes: "Let us determine- solidify- what is the movement of Gods mind ( $\pi \eta^{\gamma} \gamma v \mu \mathrm{u} / \pi \eta \dot{\chi} \chi \eta \eta \varsigma$ ), (For god is not useless or uninitiated to me) before he fashioned the visible world. Who for ages emptied/exercised his most highest rule, moving goodness which produced radiance through his mind, (observing in his mind $\theta \eta \varepsilon v ́ \mu \varepsilon v o \varsigma / \Theta \varepsilon \alpha ́ o \mu \alpha \imath)$, Threefold Divine harmonious light in equal excellence, As one Divinity,

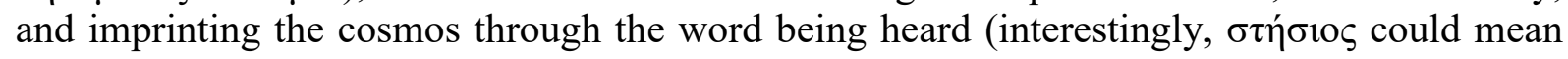
Zeus -a play on words). It is one great thought of the cosmos creating mind. Later being the

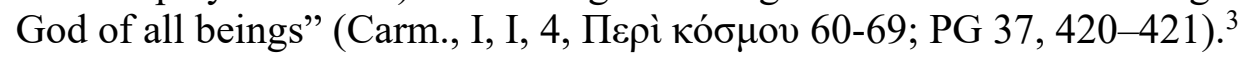

These verses describing God are of paramount importance just as the other statements in the other parts of this poem. The verses describe the unceasing activity and beauty of God, who was reigning for ages and this reign is a form of activity here. Importantly, it also mentions

\footnotetext{
${ }^{2}$ For Gregory's orations, I have offered the text from Nicene and Post-Nicene Father (Gregory of Nazianzen, 1894). However, I have altered the translation in some areas according to the original text (Grégoire de Nazianze, 1978; Norris, 1991). For the other citations of Gregory, not from the Orations, I have used my own translation (Gregory of Nazianzus, 2011).

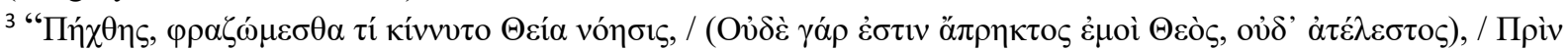

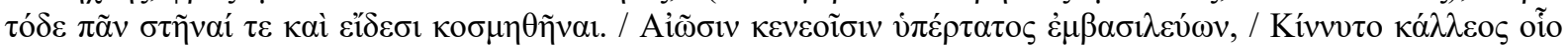

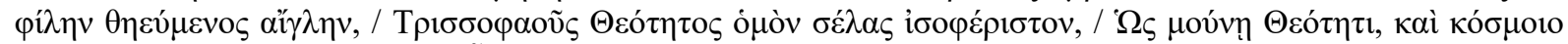

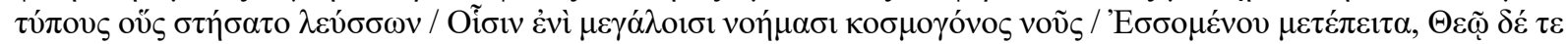

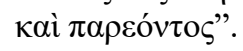


God's mind or thinking process, which is presumably linked with his creativity or contemplation of beauty.

We can state that an important conclusion which generally stems from Gregory's thoughts and not noticed by modern commentators is that the Divine "substance cannot move", since movement essentially means a change or transformation, which means that a substance cannot remain attached or synchronised to its expression/image and in an abstract sense then cannot express itself as full truth, since it is by virtue of movement "moving" and "untrue" to its own essence. Of course, here we mean by "movement" a more complex category not physical movement only. Generally, the negative connotations about movement is that it entails a change from one's position which belongs to substance at least in the abstract sense. Thus, a moving substance means a substance which through movement somehow loses its former trace and position and therefore "part of its substance". This is very important to emphasise because otherwise the theology of the image so prominent in patristic thought is left incomprehensible.

However, through contemplation, emphasised by Gregory, this issue is partly overcome since contemplation is static in a sense even though being dynamic at the same time. Contemplation paradoxically entails a dynamic/stationary position.

In Oration 28, Gregory discusses the character of God and his substance. "For what effect is produced upon his Being or Substance by His having no beginning, and being capable of change or limitation? Nay, the whole question of his Being is still left for the further consideration and exposition of him who truly has the mind of God and is advanced in contemplation". "Here the important thing to mention is that in the English translation of Brown and Swallow the term Hypostasis is missing. The term Hypostasis is of paramount importance here since it relates to the central concept of how a substance expresses itself; that is, through personhood.

In his theological oration 5, Gregory observes: "But it is not possible for me to make use of even this; because it is very evident what gives the ray its motion; but there is nothing prior to God which could set Him in motion; for He is Himself the Cause of all things, and He has no prior Cause. And secondly because in this case also there is a suggestion of such things as composition, diffusion, and an unsettled and unstable nature...none of which we can suppose in the Godhead. In a word, there is nothing which presents a standing point to my mind in these illustrations from which to consider the Object which I am trying to represent to myself, unless one may indulgently accept one point of the image while rejecting the rest" (Or. 31 (5), 33, 1$10)$. This last statement is a clear manifestation of the theologian's limits or more precisely the limits of the image to "fully express" itself. What does this mean for the theology of the image? This line of thinking leads Gregory to reflect on imagery generally and its relationship to what the image depicts or to its archetype. Here image is not only a mental or verbal picture, it is all physical and mental reality and for our purposes even virtual reality. The more one desires to touch such an image, the more it escapes. The question is then, for Gregory do images have any relation to truth?

In the first theological oration, Gregory observes: "Not to everyone, my friends does it belong to philosophize about God; not to every one (Ov̉ $\pi \alpha v \tau$ ós, $\tilde{\omega}$ oṽ $\varphi \imath \lambda о \sigma o \varphi \varepsilon i ̃ v, ~ o v ̉ ~ \pi \alpha v \tau o ́ s)$ the Subject is not so cheap and low; and I will add, not before every audience, nor at all times, nor on all points; but on certain occasions, and before certain persons, and within certain limits. Not to all men, because it is permitted only to those who have been examined, and passed masters in contemplation, and who have been previously purified in soul

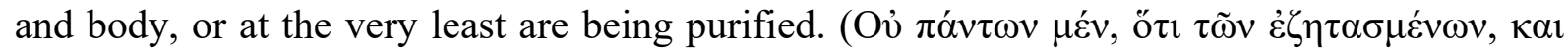

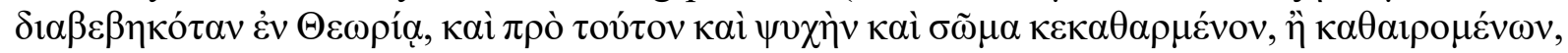

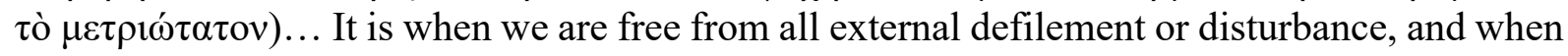

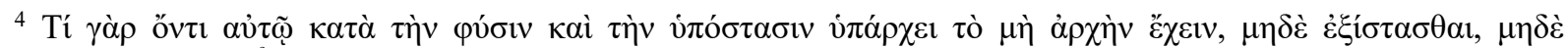

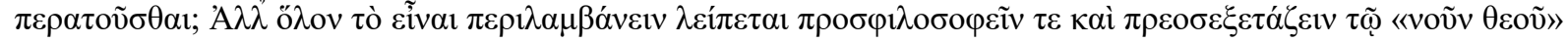

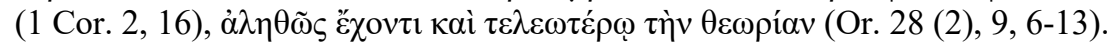


that which rules within us is not confused (i்

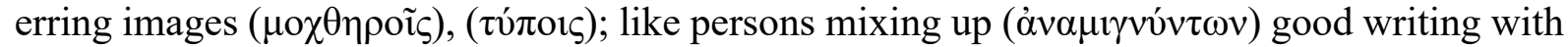
bad, or filth with the sweet odours of ointments. For it is necessary to be truly at leisure to know

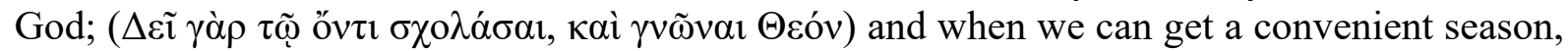
to discern the straight road of the things divine" (Or. 27 (1) 3, 1-15).

Gregory continues to argue that the subject of theology is so lofty that it cannot be subdued by discussions at the table, dinner or theatre. People who are low, often enter futile arguments ( $\dot{\varepsilon} \rho \varepsilon \sigma \chi \varepsilon \lambda i \alpha)$, into self gratyfing discussions and nice contradictions ( $\dot{\alpha} v \tau \imath \theta \dot{\varepsilon} \sigma \varepsilon \omega v)$. The discussion here obviously understands the possibility of "meditation" about things divine commensurate to the degree of purification one undergoes. Discussing things divine without preparation means that these are mere images "without meaning" and therefore liable to be subject to profanity. Here, a particularly important thought is present. It is as if the very content of the theology in question gains substance to the degree of the reality it expresses, which itself is conditioned by purification. There needs to be an external and internal connection between theology and its substance. This can be achieved when this theology gains life through purification, since it is actualised. It becomes a living theology, and therefore a substantial theology. However, the un-purified person is unprepared to unlock the substance of theology, and therefore he or she seemingly can speak about theology but this is merely an image of theology even though the subject and theme can be the same. Thus paradoxically, both the purified and un-purified person can speak about, let's say, Christ's natures, but each will understand and express this theology in a different manner even though the subject is the same and the content is the same. This is the danger Gregory points to here, that in his own day, people could speak about the same subject and then wonder why everybody reached different understandings. Gregory is annoyed here, since the Sophists are doing exactly this. This deliberation leads one to state that one's discussions about theology are always limited to the degree of the preparedness of the audience, etc. Sophistic theology is theology of images without substance.

Here one can be reminded of the interesting iconoclast discussions which later revisited the issues of images in this context. Interestingly the later Patriarch, Nicephorus, used important terms associated with our theme. Thus, he spoke of essential qualities (ovotó $\delta \varepsilon 1 \varsigma$ $\pi$ oló $\tau \tau \varepsilon \varsigma)$ and indicative properties $(\pi \alpha \rho \alpha \sigma \tau \alpha \tau \imath \kappa \grave{\alpha} i \delta i \omega ́ \mu \alpha \tau \alpha)$ and further, in relation to Aristotelian relatives, he defined the image as related to the pattern, calling it a relative notion ( $\tau \tilde{\omega} \nu \pi \rho{ }^{\prime} \varsigma \tau \imath$ ) as the effect of a cause. "[...] the icon possesses a relation to the archetype as the effect of a cause. Therefore, it is necessary that the icon both be one of the relatives and be called such" (Goncharko \& Goncharko, 2017, pp. 298, 302).

\section{Are images and virtual reality deceptions in their own right?}

In patristic thought generally, especially the tradition of fathers associated with the tradition of the Philokalia and hesychasm, "images" seem to have a bad reputation. Often images are associated with that which cause temptations and problems. Especially "images in the heart". Gregory of Nazianzus with his emphasis on beauty and contemplation, however, seems to present a useful corrective to this line of thinking, because in any event "imagery" is linked to beauty. How can we reconcile this positive and negative opinion about imagery? Already Plato established the fundamental problem of the image, imprint and the original. ${ }^{5}$

In order to understand the idea of the image, we would also have to address the complex theology of the creation of man in the "image and likeness of God" (Gen. 1, 26-27; 5, 1; 9, 6; Jas. 3, 9 etc.). We do not have the possibility of entering a discussion on the theology "of the

\footnotetext{
${ }^{5}$ See the Theaetetus of Plato. Modern philosophy often recapitulates the discussion already found in earlier authors. Thus, the patristic tradition already firmly established the discussion of the dynamics between image, imprint, mimesis and the original, typos (Ricœur, 2004).
} 
Image and likeness" as developed on the basis of the Greek Septuagint. The idea of the image and substance, imprint and prototype, archetype played an important role in the formation of patristic thought.

Suffice it to say that in authors such as Gregory, we cannot discern a tension or still better a negative stance towards the image in contrast to its prototype. Gregory writes in the context of the Divinity of the Father and Son in his Fourth theological oration: "And the Image as of one substance with Him, and because He is of the Father, and not the Father of Him. For this is of the Nature of an Image, to be the reproduction of its Archetype, and of that whose name it bears; only that there is more here. For in ordinary language an image is a motionless representation of that which has motion; but in this case it is the living reproduction of the Living One, and is more exactly like than was Seth to Adam, or any son to his father". ${ }^{6}$

There are two levels of meaning here. If we understand creation/the human being as a kind of image of its prototype, this image cannot be understood as a negative image. However, the problem that the fathers point to is, that, due to sin and other factors, the image no longer corresponds to its prototype or archetype. This is not a permanent condition but is linked to the degree of our sin and rebellion as human beings. Thus, understandably, such a deformed image (including images in our heads and heart) cannot be good for our spiritual well-being. However, there is also another problematic dimension. Any unqualified intimate relationship between the image and its prototype encounters a problem, since, in Christian theology, the Divine substance, can never be fully explored. At first glance, therefore, the image can never be equal to its substance or to the archetype. This would presume a position of inferiority for the image. In terms of Gregory of Nazianzus and his school of thought, this is not really a problem. The image regardless of its distance from its prototype is never really inferior, since it offers each individual and observer a window to beauty through contemplation equal to the degree of perception available to each person. Any image leads to another image as a wonderful dynamic movement towards beauty which is an endless process just as God's substance is noncircumscribable in its nature. Therefore, no image is inferior since it is related to the Divine substance in a dynamic movement of the contemplation of beauty. Gregory observes: "So that no strangers would have the advantage over us, I say this in coloured language, even though the beauty for us is in Contemplation. For you it is necessary to play with wisdom. For us it's a lion's pleasure. To fourthly find the disease from which suffering stems". 7

In Oration 30 Gregory mentions the ancient Judaic restrictions on naming God. He cannot be expressed by "divisible" words. ${ }^{8}$ Further, he writes: "But we sketch Him by His Attributes, and so obtain a certain faint and feeble and partial idea concerning Him, and our best Theologian is he who has not indeed discovered the whole, for our present chain does not allow of our seeing the whole, but conceived of Him to a great extent than another, and gathered in himself more of the Likeness or adumbration of the Truth, or whatever we may call it". 9 The term

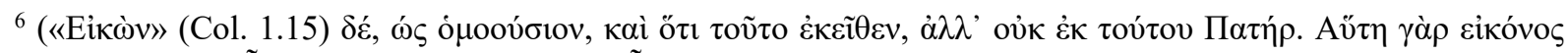

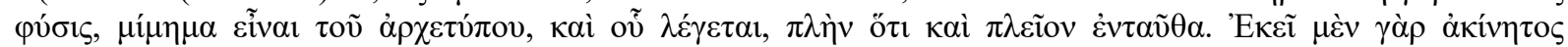

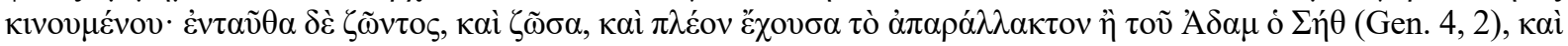

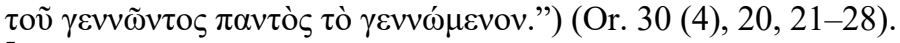

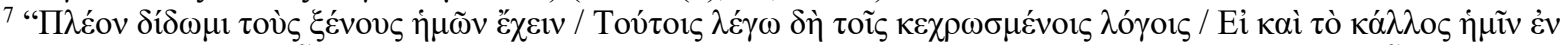

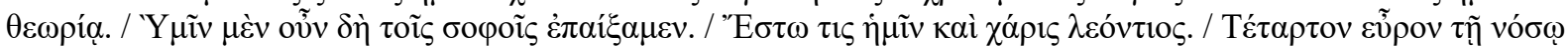

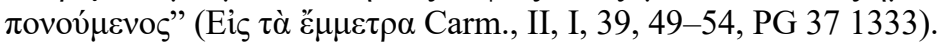

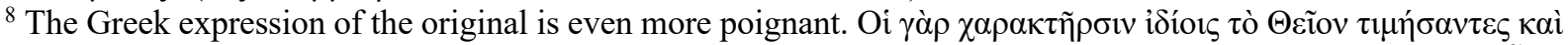

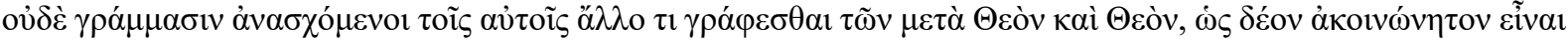

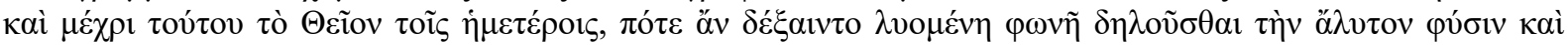

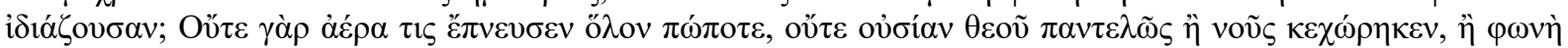
$\pi \varepsilon p \iota \dot{\lambda} \lambda \alpha \beta \varepsilon v$ (Or. 30 (4) 17, 4-9).

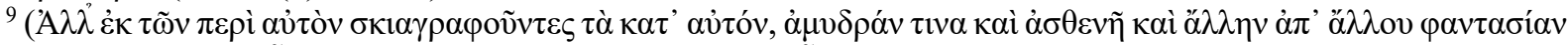

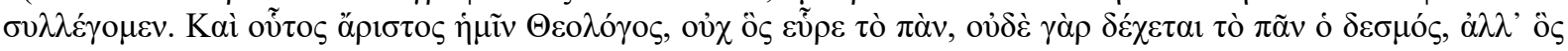




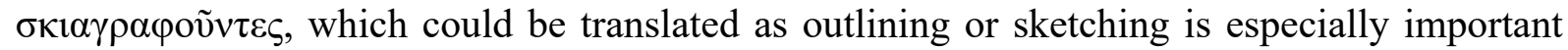
here. It is also related to rhetorical discussions of God and his divinity.

Perhaps it is unsurprising that the later Byzantine writer Michael Psellos found so much in common with Gregory of Nazianzus, whom he admires. Just as Gregory before him stressed beauty and contemplation as a key to unlock the dynamics of our life, so Michael Psellos rediscovers this concept in the later Byzantine world. To what extent does Psellos remain in the standard framework of Patristic thought in this context remains subject to debate (Barber \& Papaioannou et. al., 2017; Papaioannou, 2011). ${ }^{10}$

Gregory continues to observe in his second theological oration: "Therefore, this darkness of the body has been placed between us and God, like the cloud of old between the Egyptians and the Hebrews (Exod. 14, 20); and this is perhaps what is meant by He made darkness His secret place, namely our dullness through which few can see even little". ${ }^{11}$ Further "so it is quite impracticable for those who are in the body to be conversant with objects of pure thought apart altogether from bodily objects. For something in our own environment is ever creeping in, even when the mind has most fully detached itself from the visible, and collected itself, and is attempting to apply itself to those invisible things which are akin to itself'. ${ }^{12}$

If Gregory had the occasion to live in our age, he would probably ask himself if reality itself is a problem for us in seeing the truth and God, is it not the case that virtual reality would be an even greater problem? If virtual reality is further removed from reality, how much more is it removed from the truth? If it is difficult to discern aspects of reality in the world surrounding us, is it almost impossible to see it in "virtual reality". The only thing that Gregory would probably agree on here is that, obviously, reality is a kind of "pointer" to higher things. This is of course the same with virtual reality, since even in virtual reality, we are driven to other objects behind it. We may speculate whether virtual reality does not push us towards greater oblivion, if oblivion is understood as the absence of reality/substance.

On one plane the imagery in virtual reality can push the relationship between what is real and what is interpretation or illusion to further extremes, especially given the obvious limits of virtual reality itself. The fundamental issue at hand is that if reality itself or its objective existence can be a source of our own illusion and delusion is it not true that "virtual reality" is even further in danger of distortion of the truth? Here the issue is not only linked with the Divine, but with reality as such. One may argue that this distortion of the truth in the image is only linked to the Christian presupposition of morality and sin. But this is clearly not the case, since any basic non-theist philosophy has to admit that there is a problem in our perception of reality, truth etc., regardless of moral notions of sin and other concepts.

Gregory emphasises the fact that one needs guidance through the field of knowledge and contemplation. The contemporary stress in humanist schools is that reality is objective enough and one does not need to have any guidance whatsoever apart from general abstract ethical principles which, however, cannot in their own right have no grounding since they are relative to the desires and needs of contemporary society. Gregory speaks of the Spirit as a guide. We may ask whether the observer living in virtual reality needs such a guide or if such a possibility of a guide indeed exists. The world without rules, which is the internet, does not have a guide.

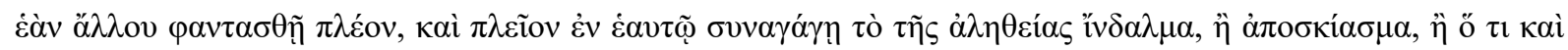

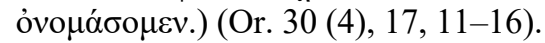

${ }^{10}$ However, the relationship between Psellos and Gregory of Nazianzus has not been sufficiently explored in modern scholarship in terms of the philosophy and theology of beauty.

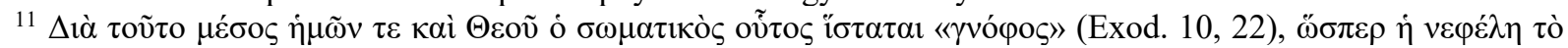

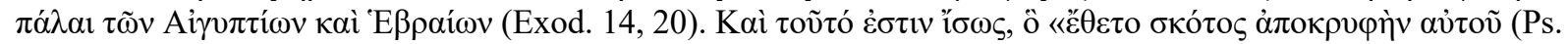

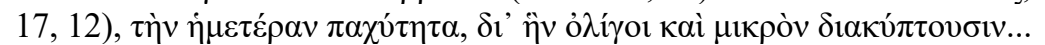

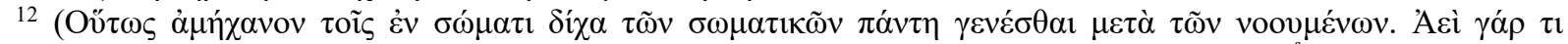

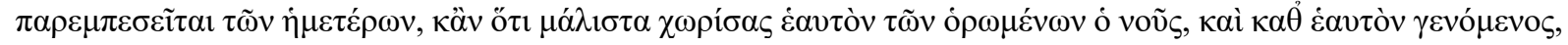

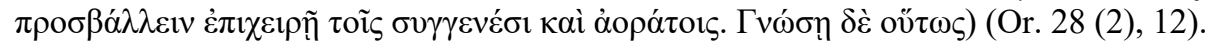


There is a liberation offered by Gregory from the reality, or virtual reality, of moving images seemingly without order and sense. Without a guide (just as is the case with the internet), there is a risk that we will be lost. However, this guide cannot be static itself otherwise it will be just another image. For Gregory it is the Holy Spirit. Here in the thoughts of Gregory and others the Spirit is something more than a Divine being. It is the spirit of unpredictability. To be more precise, only a "spirit" can manoeuvre in a complex virtual world or any world at all, since nothing is defined in advance. The association of the freedom of spirit with the internet is a theme not commented on by any contemporary author. The Divine Spirit in Christian life is a spirit of freedom and unpredictability, which however has its beginning and end in Christ understood here as the ultimate grounding of reality and truth. This notion could be useful for understanding the dynamics of virtual reality, if it assumes that the spirit of freedom which is inherent for example in the internet is indeed a spirit leading somewhere or from somewhere (without any moral or ethical judgements involved).

For Gregory, the Christian Holy Spirit is something present everywhere, it is "indwelling" in the human beings $(\Sigma v \mu \pi \mathrm{o} \lambda \imath \tau \varepsilon v \omega)$, (See oration 41$)$. Therefore, it is communion building in its nature. The Holy Spirit seems to reveal itself gradually on a certain level. This seems to be the import of Oration 41, 11, where the Spirit gradually manifests himself. Importantly, Gregory uses three terms $\dot{\alpha} \mu \nu \delta \rho o ́ \varsigma, ~ \varepsilon ̌ \kappa \tau v \pi o \varsigma, \tau \varepsilon ́ \lambda \varepsilon 10 \varsigma$, to demonstrate the gradual manifestation of the Spirit until a perfection of manifestation. Importantly, he speaks of expression through energy which then also culminates in a substantial manifestation ( $\dot{\varepsilon} v \varepsilon \rho \gamma \varepsilon i \alpha$ / ovं $\sigma \omega \delta \tilde{\omega} \varsigma)$. The idea of a kind of self-revelatory and revelatory role of the Spirit appears elsewhere, like for example in

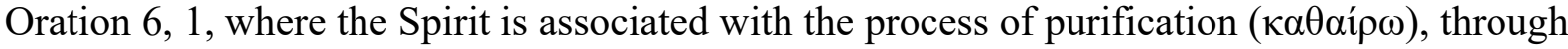

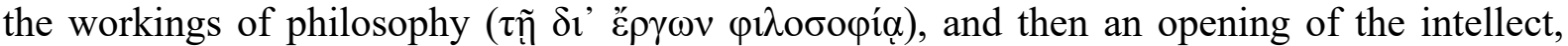
which receives in the Spirit (Ps. 119, 131), which leads to a good word ( $\lambda$ ó $0 v$ o $\alpha \gamma \alpha \theta$ óv), which

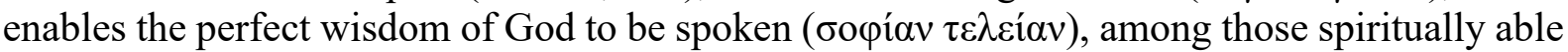

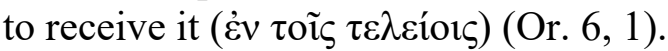

In our own spiritual makeup, we have, apart from the spirit or Holy Spirit, instruments of discernment, which are the physical and mental abilities to discern between images, concepts and so on. Therefore, encountering the image and its perception is not a static direct encounter, unmediated by a filter. We have unique organs which help us discern truth and reality which derive their objectiveness only by reference to a Divine Creator. Otherwise they would be relative. Gregory associates the nous with taxonomic qualities. ${ }^{13}$ The Nous is the inner vision, which is not circumscribed. The work of the nous is thinking, about the impressions (imagining?). The faculty of "reason" is an inquiry on the impressions or images of the nous,

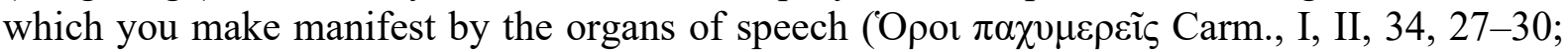
PG 37, 947-948). ${ }^{14}$

The important point here is the impression of the senses on the nous, which come from the outside and presumably leave an imprint. It is obvious, and we may conclude, that the nous then classifies these thoughts according to certain criteria. I do not want to use the word "reason" here because of its ambiguous meaning. ${ }^{15}$

The nous can be linked with reason. Reason in the patristic tradition is a complex reality. The patristic understanding of the nous and reason is linked with a complex and organic

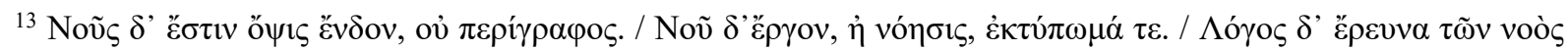

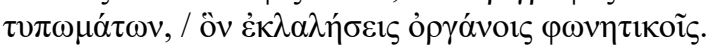

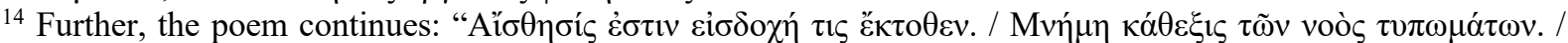

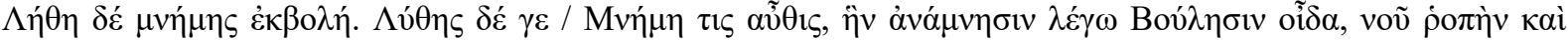

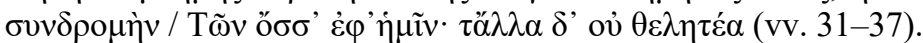

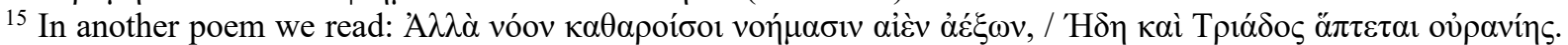

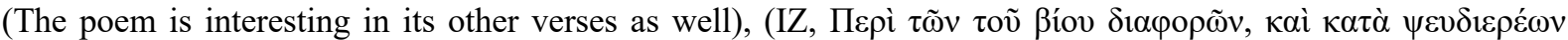
(Carm., II, I, 17, 35-36; PG 37, 1264). However, the mind cleans the thoughts always increasingly, as the Trinity touching heavens.
} 
understanding of the human person. The radical separation of rationality and reason from the overall human person, so adamant in modern philosophy and thought, was unknown to the patristic tradition. This is important even for our purposes since, if one is to understand our relationship to reality and virtual reality, a more holistic understanding is useful.

Neuroscientists such as Damasio, have increasingly called for a more holistic and inclusive understanding of emotion and reason. For a "comprehensive understanding of the human mind requires an organismic perspective" (Damasio, 1994). He addresses the issue of how reason interacts with emotions and thoughts. Importantly, he argues one cannot immediately and clearly ague that reason operates independently from other process including emotion, images and so on. The patristic tradition sees an interconnectedness of all these organs and aspects. This interconnectedness then enables us to interact with reality and virtual reality.

An interaction which sees a congeniality between the human being and the universe since the human being is a microcosmos. The obvious issue is, if virtual reality is a "reality" at all, it must be linked internally in a dynamic of interrelatedness with the human being and his or her internal and spiritual organs. Ironically, this would please the most dominant individualistic philosophy, where the "I" is in the centre.

This microcosmos aspect of the human being is also linked with the fact that we are, according to the Judaeo Christian tradition, intimately linked with God by virtue of being his creation. The believing Christian of course has recourse to perfect images, being himself or herself made in the image and likeness of God. The human being made in the image and likeness of God, can "recall" true images by reference to his divine origin. This recollection guarantees the truthfulness of reason since it operates with true images. This enables us through images to

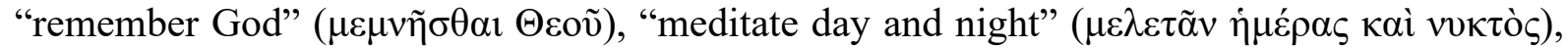

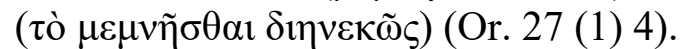

If this is so we can argue using the term mimesis, that without this connection to Divine substance, (artistic) mimesis -just as Plato and Aristotle argued- cannot accurately express reality. The simplicity of God can be related to the "unseen" God. in fact, many fathers of the church especially Gregory of Nazianzus tend to speak of the simplicity of God. For example, a modern theologian writes: "A single quest and a single search must be substituted for all these questions. To seek God, to avoid the inner turmoil of overly subtle investigations and disputes..., to flee from the other noise of controversies and to eliminate futile problems, such is the foremost note of simplicity..., "holy simplicity" is the humility, which safeguards the integrity of the mind, which ensures the search for God alone. All these including intellectual pursuits should remain subordinate to the search for God" (Leclerq, 1960, p. 254).

The emphasis on the simplicity of God, also presents certain challenges for the notion of love. Plantinga generally addressed problems related to God's simplicity some years ago. Thus, he writes: "According to Augustine, God created everything distinct from him; did he then create these things? Presumably not; they have no beginning. Are they dependent on him? But how could a thing whose non-existence is impossible - the number 7, lets say, or the property of being a horse---depend upon anything for its existence? Does God (so to speak) just find them constituted the way they are? Must he simply put up with their being thus constituted? Are these things, their existence and their character, outside his control?" (Plantinga, 1980, pp. 4-5).

\section{The matrix nature of virtual reality}

The central question related to virtual reality is whether it has any relation to substance. We do not have the space here to justify or refute the traditional emphasis on substance in the patristic tradition. However, we can agree that reality by virtue of being reality has to have some connection with what one may term "substance" understood as a real basis for the materiality 
of all existence. Whether this substance is associated with matter or something else is another issue.

The most negative aspect of, for example, the internet is undoubtedly its "matrix" fabric. The internet offers seeming endless freedom of information and action but all its aspects, including information, are programmed and are preconceived. Regardless of our perception, one cannot escape the matrix of pre-conceived planning and programming. This is the greatest danger of the internet or other forms of virtual reality. Of course, anyone can state that even the world around us offers a kind of preprogramed or predetermined reality. What is the difference between virtual structures and real structures in terms of volition? The difference is that the human being is the subjective force of human created virtual reality, whereas the human being has no control over nature and the world as such (at least not in an absolute sense). Thus, there is a reality beyond human control and therefore $i s$ reality. Whereas human made virtual reality is an artificial reality which at least now is controlled by the human being.

If one looks at social media such as Facebook, one can never enter a discussion from the "outside", since one must operate within the framework of social media and its elements. Entering a discussion on social media means accepting the rules and logic of argument herein. Here we do not mean simply rules for discussion but the limits for such a discussion set by the character of the media itself. This "binary" discussion does not necessarily produce anything new or a synthesis. Because all synthesis is limited to the conditions it stemmed from. It does not have a truthful and therefore independent existence.

Gregory held syllogistic and dialectical arguments in disdain, since he believed that argumentation cannot always produce truth, since one argument is countered by another without a tangible result. This kind of reflection leads us to suggest that even internet social media does not offer "a way out" of its own forms of discourse, which could succumb to being mere images and elements of discourse without a "liberating form". Even if there is a product, it is a product of the matrix of the internet and its reality.

In his second theological oration, Gregory comments on the possibilities of knowledge of God or things states: "inasmuch as it is easier to take in some single point than to go on disowning point after point in endless detail, in order, both by the elimination of negatives and the assertion of positives to arrive at a comprehension of this subject". ${ }^{16}$ Gregory, generally in his theology, avoids a theology which would subscribe to an exchange of arguments or positions, since he believes that the truth lies somewhere above or outside general discourse of this sort. ${ }^{17}$

The question is whether one's limits in the way one argues does not limit in advance the form of conclusion and truth one reaches. In terms of virtual reality this seems to be even more pronounced.

\section{Imagination and virtual reality}

Virtual reality can be linked with imagination if imagination here means an expression of unhindered and free movement of the mind and body. One of the positive aspects of virtual reality is its ability to offer a seeming limitless platform for imagination. A person designing a computer game or other forms of media can be free to design objects and spaces which would otherwise be impossible in the "real world". The proponents of virtual reality often point to this positive aspect of virtual reality. Gregory, as we have implied, stresses the beauty of creation and God which is linked with imagination. This beauty is linked with the absolute imagination

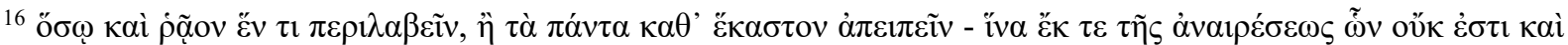

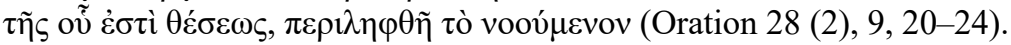

${ }^{17}$ Interestingly enough, in the medieval period Gregory was associated with logic and as being a commentator on the quadrivium (Heiberg, 1929).
} 
of God unparalleled in the universe and carried necessarily in the spirit of freedom since freedom and imagination go together.

The central question one may ask is; is this proposition true? Is virtual reality, in fact, an area offering limitless freedom and a platform for imagination? If we link imagination and freedom to the thoughts of Gregory of Nazianzus, interesting insights can be gained for an overall assessment of imagination and virtual reality. There are two main issues to be considered. Firstly, imagination does not automatically have a good reputation in ascetical writings, as it is linked with sin. But this does not mean that imagination is altogether rejected. On the contrary, Gregory of Nazianzus clearly sees in imagination one of the most important aspects of the creative force and love of God. Imagination must, however, be qualified. Imagination is a vehicle of contemplation and in this sense it is positive; a contemplation of the objective forces of creation. One is here reminded of the Stoic conception of phantasia. ${ }^{18}$

However, our own imagination, as a subjective and limited expression, can be dangerous since, paradoxically, the more imaginative we are, the less imaginative we actually are because our subjective imagination in the end limits this imagination, because it is based on our own limited and circumscribed vision. However, if Gregory sees a contemplative moment it does not mean that the human being is simply a passive observer through the medium of imagination. Imagination is a vehicle to see beauty, without imagination there is no possibility of seeing beauty. Although, in order to do that, one needs to ascend to these impressions in a spiritual assent.

Of course, generally, we can state that the images as imprints on the mind have a bad reputation in some patristic authors. For example, perhaps Evagrius understands the images and impressions as inherently problematic (Clark, 1992, p. 75) since they enter the mind and, once there, involve themselves in a battle. The passions play a role here in the negative absorption of these images. On a first reading, such theories obviously can lead to an idea of a completely passionate mind which is difficult to reconcile with the loving heart scheme and other contemplative modes of thinking. As we have indicated, Gregory of Nazianzus offers a corrective vision to this extreme position. The problem is not with the images but with how "one absorbs" them so to speak.

In terms of the internet, for example, one can only wonder how negative would Evagrius be if he had known that the internet sends out only images of all sorts. If reality is suspicious itself then even virtual reality with even a lesser correspondence to substance is even more dangerous. For Gregory, the main reflection point for understanding images, exegesis and all related concepts is by reference to the Trinity itself, where it is, above all, obvious that certain conceptions cannot be maintained about the Divinity. Of course, other philosophical schools were not limited by this theological postulate central to Christianity. However, the Triune God, with his substance beyond understanding, was a powerful exegetical condition for any reflection. Thus Gregory concludes his fifth Theological Oration by stating exactly that "Finally, then, it seems best to me to let the images and the shadows go, as being deceitful and very far short of the truth; and clinging myself to the more reverent conception, and resting upon few words, using the guidance of the Holy Ghost, keeping to the end as my genuine comrade and companion the enlightenment which I have received from Him, and passing through this world to persuade all others also to the best of my power to worship Father, Son and Holy Ghost, the One Godhead and Power. To Him belongs all glory and honour and might for ever and ever. Amen" (Or. 31 (5), 33).

\footnotetext{
${ }^{18}$ For an interpretation of Stoic phantasiai in terms of an "awareness" of the world (de Harven, 2018).
} 


\section{Contemplation}

For Gregory, the central instrument for viewing and understanding the cosmos and its beauty in an objective way is through contemplation. Here, contemplation is a form which guarantees that our perception of the cosmos and creation is not based on a defective subjective platform but on a purely objective platform. This is guaranteed by the contemplative assent which only absorbs, so to speak, the images and beauty it receives without classifying it in an a priori move. This does not mean that the contemplative is some kind of passive sponge absorbing all around him, but it simply means that one is open to any impulse by virtue of not relying on an a priori taxonomic platform. This is very important to emphasise. Usually all the images that we receive enter our senses and we classify them according to our predetermined biological makeup and on the basis of previous psychological experiences, which of course then limits our freedom of seeing things "as they are". As we have discussed, the patristic tradition believes that we see things through a glass darkly precisely due to our sin or other factors, which prevents us a priori to see things in an objective light and therefore true light.

This contemplation is a never-ending process since God in his being can never be circumscribed by any form or creature of creation. In other words, we move from beauty to beauty, from glory to glory. Thus, in a way one can never be "bored" of a problem which was popular with medieval theologians. Gregory observes in his second theological oration: "Thus Solomon, who was the wisest of all men $(1 \mathrm{Kgs} .3,12)$, whether before him or in his own time, to whom God gave breadth of heart, and a flood of contemplation, more abundant than the sand, even he, the more he entered into the depth, the more dizzy he became, and declared the furthest point of wisdom to be the discovery of how very far off she was from him" (Oration 28 (2), 21).

In the same second theological oration, he writes: "Combining all things in one, solely with a view to the consent of the Creator of all things; Hymners of the Majesty of the Godhead, eternally contemplating the Eternal Glory, not that God may thereby gain an increase of glory, for nothing can be added to that which is full - to Him, who supplies good to all outside Himself but that there may never be a cessation of blessings to these first natures after God" (31).

Contemplation also, however, leads to a sense of unity and truth and a revelation of truth when one understands the true nature of reality and objects and beings around him. He observes in the above already cited poem: "So that no strangers would have the advantage over us, I say this in coloured language, even though the beauty for us is in Contemplation. For you it is necessary to play with wisdom. For us it's a lion's pleasure. To fourthly find the disease from which suffering stems". ${ }^{19}$

Here of course, contemplation is something different from prayer. Prayer is a dialogue or monologue, but contemplation is a state of being or awareness, which offers a unique perspective on things because it is liberated from one's own disposition and limits any preconceived notions. In psychiatry, the patient often must confront his or her previous experiences in order to find healing. This is similar in a way to a contemplative mode.

In terms of virtual reality, one may ask whether the images offered are indeed possibilities for contemplation in the objective sense of the word. The issue is that human made virtual reality as a creation of the human being is a subjective construct based on the imagery produced by an individual or individuals, which themselves, in our scheme, are subject to the imprisonment of their own limited and subjective worldviews in the same system as we have described above. The contemplative cannot be sure whether he or she is contemplating anything in virtual reality since this virtual reality is only an image or a prototype of some sort. Thus, in

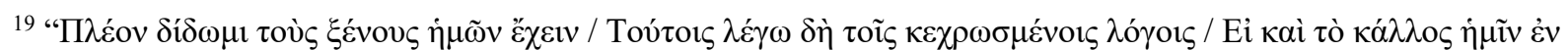

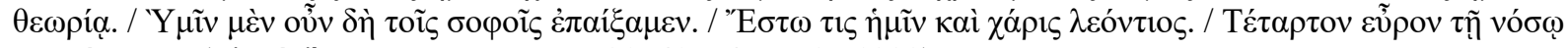

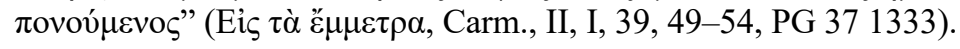


the worst-case scenario, the contemplative is simply lost in an ocean of illusion preventing any form of contemplation.

Interestingly, such a problem was related to poetry in Greek philosophy. Poetry can result in deception and a reliance on subjective emotion. This subjective emotion can prevent the poet from offering anything truly objective apart from his own or her emotional disposition. Plato had a reserved position towards poets. According to Plato, poets can deceive the public because "they are like a portrait painter who cannot catch the likeness" (Plato Rep. 2, 377-383; McGuckin, 2006, p. 198) McGuckin argues that Origen and Gregory reconciled the situation by arguing that the poet must be, at the same time, a philosopher. This would alleviate the negative aspects of poetry (McGuckin, 2006, p. 198).

This leads us to consider rhetorical art. As the art of persuasion (according to its ancient understanding) it is obviously limited in its scope of portraying the truth. If rhetorical art aims to persuade about any form of proposition this, in essence, means that it is not concerned with truth but only with persuasion. Obviously, we can refer to the internet here and point to the negative flows of information aiming to persuade and convince without any moral grounds.

However, rhetorical art in Gregory has a clear aim and goal, which is important. It is the art of expressing the truth. For Gregory, there is a clear correspondence between what is stated and its content. There is no divorce between content and its expression. The true rhetor is not a Sophist, and his goal is not to persuade but to attain truth and, therefore, happiness. Of course, even Plato discerned between forms of truth. This is seen in the different ways he treats rhetoric in the Phaedrus and the Gorgias (Freese, 1952, p. xx).

According to Gregory, rhetorical art offers us a verbal expression of truth since there is an internal link between verbality and substance. Rhetorical art offers us a way of describing the utter beauty of creation. In a sense, Gregory stands in line with the later byzantine humanists such as Psellos and others.

Importantly, the internet and virtual reality as such can be a platform for endless and useless "babble", which Gregory detests. Looking at his first theological oration (27), one can read his disdain against those who "babble". Here, one might recall a story in Psellos himself when he experiences a vision after which he babbles. Psellos does not look at babbling in such a negative way in this particular story.

In the first theological oration (A Preliminary Discourse Against the Eunomians), Gregory writes: that there are those who use the "word" to display their pride (Прò $\tau_{\text {ò̀ }} \dot{\varepsilon} v \lambda$ ó $\gamma \omega$

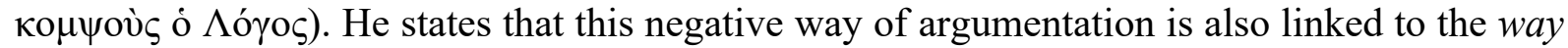

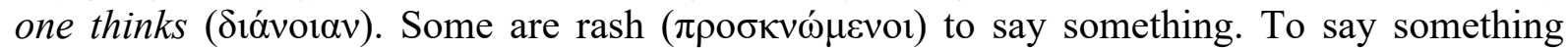

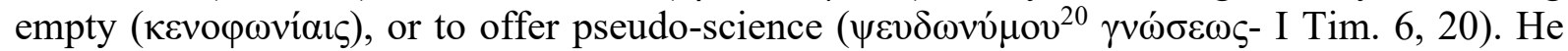
continues to state that people engaging in empty discussions should concentrate on linking their speeches with practice. If they are linked with practice, they will perhaps become less sophisticated and less paradoxical and no longer useless acrobatics $\left(\kappa v \beta 1 \sigma \tau \alpha i^{21}\right)$. They will no longer speak senselessly about a sensible subject" (Or. 27 (1), 1, 1-16).

\section{Communion and virtual reality}

The internet, just like virtual reality generally, has serious implications for the development of communal aspects. As we have argued, virtual reality can provide a certain deception of imagery and persons. Similarly, as for ancient philosophers, poetry and rhetoric in their negative

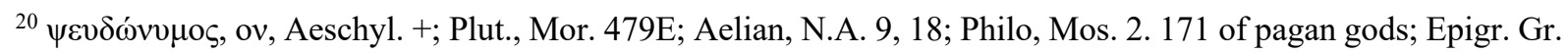
42, 4. - carrying in a false way a name, or the gnosis of heterodox Christians., (1 Ti 6: 20. M-M).

${ }^{21}$ In sources we learn about further forms of the term 'Chrétiennes', which are not offered by the dictionary of Lidell-Scott, especially as they appear in Homers Elias, 16, 750, Odysseus 18, 605, Odysée 4, 18. Platón Banquet 190a.
} 
aspects, could mean that one adopts a different persona or image, deceiving a community of people and individuals.

As we have implied for people such as Gregory, communion and communion with God is a necessary criterion for enabling us to realise whether we are objective or not. Communion and community is one of the realities that helps the individual to realise whether he or she is subjective or truthful or not. This is obviously the main principle behind ecumenical councils and councils of the church, where the truth should appear. If one takes social groups on the internet into account, one can ask whether this kind of form really offers a communal experience or community. Social media offers a variety of forms of communication, which are positive in many aspects. Especially for those who are handicapped and have various forms of disabilities, this form of communication is often the only form available.

However, having said that, one must ask, the central question whether the internet does not offer a hidden form of personhood. A person in social groups on the internet can and often does present a different persona than he or she really is, either intentionally or not. The person presenting himself or herself on the internet assumes an alter ego. Even if there was a sincere desire on the part of the person to present herself or himself on social media in the most objective and truthful form, there are limits of communication and expression which limit this but this is not what interests us here.

In normal reality, for example a village or city, one lives in a community where one is responsible for his or her surroundings, since he is being directly and indirectly observed. The person can project to his or her surroundings some form of character or image which, however, is "corrected" in some way or another through the lenses of the community. The entire church and its history are about this concept of communal supervision; a supervision all the more stressed in the Old Testament. The Greco/Roman concepts of the politeia are exactly built on this fact as well. In virtual reality one can be controlled, in a good sense, by the social community he or she is a member of but this control is again only partial and inadequate by virtue of being unable to go outside of its limits.

As has been discussed by some philosophers, virtual reality offers sources for reflection which, as we have seen, are related to the patristic tradition and Gregory of Nazianzus, but also to other disciplines of philosophy. Virtual reality offers a glimpse or a metaphor of personhood and consciousness (Metzinger, 2018). For the theologian, however, the task is not only to assess the metaphors of virtual reality but to assess its negative influence generally.

\section{Conclusion}

In our, contribution we attempted to draw on some ideas related to Gregory of Nazianzus to perhaps contribute to a development of a general ethic of the manmade virtual world, which is so necessary in our period. We must live "in reality" for us, as human beings, "to be real". However, what is real and not is becoming increasingly blurred. This is the consequence of the existence of virtual reality. The question is: can one be happy in virtual reality or any other forms of reality if our own experience has shown that we are not happy even in the real world around us?

Our central argument, based on Gregory of Nazianzus is, that all reality is beautiful and worth admiration. However, the difference between artificial forms of creation, virtual reality and any form of reality lies in their grounding or, let us say, substance. It has often been argued that virtual reality and other forms of reality are a way of offering endless forms of creativity and imagination. With creativity and imagination freedom is linked. Obviously, freedom, creativity and imagination are all positive concepts. However, it is a given fact, and paradox that has often been commented on that, in actuality, forms of virtual reality, internet and other similar related realities, in effect do not offer freedom or liberation or creativity because they 
are themselves limited. Thus, there is a paradox, that the more freedom virtual reality offers, the less freedom it offers in the real sense.

The reason for the negative aspects of manmade virtual reality lies in the fact that the human being is a subjective force behind its creation. Virtual reality as the consequence of the human being's activity can become a prison based on the subjective modality of its creator. The negative aspects of the virtual world are being seen daily. Thus, the irony is, that while virtual reality is becoming part of our daily lives on a staggering scale, reality around us is slowly disappearing in the form of the destruction of nature and animals. Social media offers endless platforms for criminals hiding their persona and identity. Social media does not offer a true community or communal perspective because its community is limited by the medium itself or by the endless illusions and delusions behind which we can hide and adopt an artificial life with artificial love.

Further, there are no clear guidelines or guide through virtual reality: risking it to be a world full of empty images stimulating other images and this endless imagery without substance is without life offering only endless, encounters with images. Once one is bored with one image, he or she gets another. The destruction of senses and emotion and feeling is only a necessary consequence of this encounter with virtual reality.

As we have seen Gregory, is weary and suspicious about any artificiality because artificiality is linked to untruthfulness (in his Christian world, of course, it is called sin). He believes in the ineffable Divinity which is our principle and grounding for viewing the reality of things. All reality has to have grounding and the Divine is inexpressible, and therefore an eternal and truthful reference point for our own orientation in reality. In order to identify the images around us, which is reality itself (here images are not pictures but all physical and spiritual manifestations) one needs to know their source and lead to it in order look behind them and find their substance which authenticates them as something true and offering interaction for us. Virtual reality offers only a derivative substance, which itself is subjective. Of course, even if we argue that all reality is a virtual reality itself, this does not counter the argument, because reality around us, in the general sense, is not our subjective creation.

The human being can, according to Gregory, discover happiness and truth by reference to his being the microcosmos linking him directly to the cosmic in its entirety and its movement. This cosmic dimension based on creation from God, offers an endless opportunity to enjoy beauty and imagery. However, the difference between images linked to substance-God and images without this substance is clear. The latter produce anguish and subordination, since they lead us into an endless search for meaning and truthfulness, which, however, is not occurring since these images have no basis and are therefore not real. The human being is a microcosmos where he is inherently linked with a macrocosmic reality. This means there is no divorce between virtual and other forms of reality if one acknowledges the dynamic movement of endless beauty achieved through contemplation.

Through contemplation, Gregory safeguards this freedom of creation, because contemplation implies for, Gregory of Nazianzus, a way out of a priori subjective discernment and taxonomy. In this context, virtual reality is a form which by its very nature has to build consciousness and personhood for it to be viable for the human being. Whether one adopts a Christian perspective or not, the fact is that virtual reality cannot limit the freedom and consciousness of the human being; for it to be viable, it must build personhood and, by extension, communal life. Overall, Gregory's theology offers many insights into a future ethics of virtual reality. Gregory sees beauty and freedom everywhere in all forms of reality so to speak. However, his methodology is here to safeguard the possibility of reality to fulfil its function in building freedom and imagination. 


\section{References}

BARBER, M. \& PAPAIOANNOU S. et. al. (2017): Michael Psellos on literature and art: A Byzantine perspective on Aesthetics. Notre Dame: University of Notre Dame Press.

BREY, P. (2011): Anticipatory technology for emerging IT. In: J. Mauger (ed.): CEPE 2011: Crossing boundaries. London: INSEIT, pp. 13-27.

CLARK, E. A. (1992): The Origenist controversy: The cultural construction of an early Christian debate. Princeton, NJ: Princeton University Press.

DAMASIO, A. (1994): Descartes' error: Emotion, reason, and the human brain. New York: Penguin books.

DE HARVEN, V. (2018): Rational impressions and the Stoic philosophy of Mind. In: J. Sisko (ed.): History of Philosophy of mind: Pre-Socratics to Augustine, vol. 1. London: Routledge, pp. 214-233.

FREESE, J. H. (1952): Aristotle: The art of rhetoric. London: Heinemann.

GILYAZOVA, O. (2019): The relationship between virtual and actual reality, phenomenological-ontological approach. In: Journal of History Culture and Art Research: Tarih Kültür ve Sanat Araştırmaları Dergisi, 8(1), pp. 196-204.

GONCHARKO, O. Yu. \& GONCHARKO, D. N. (2017): A Byzantine logicians "image" within the second iconoclastic controversy, Nikephoros of Constantinople. In: Scrinium, 13, pp. 291-308.

GREGORY OF NAZIANZUS (2011): Five Theological Orations, trans. S. Reynolds. London: Estate of Stephen Reynolds.

GREGORY OF NAZIANZUS (2001): On God and Man: The theological poetry of St. Gregory of Nazianzus, trans. P. Gilbert. Crestwood, NY: St. Vladimir's Seminary Press.

GRÉGOIRE DE NAZIANZE (1995): Oration 6, ed. M.-A. Calvet-Sebasti. Paris: Les éditions du cerf.

GREGORY OF NAZIANZEN (1991): Faith gives fullness to reasoning: The five theological orations of Gregory of Nazianzen, ed. F. Norris, trans. L. Wickham \& F. Williams. Leiden: Brill.

GRÉGOIRE DE NAZIANZE (1978): Discours 27-31, Discours Théologiques, ed. P. Gallay. Paris: Les éditions du cerf.

GREGORY OF NAZIANZEN (1894): Select Orations. In: P. Schaff \& H. Wace (eds.): Nicene and Post-Nicene Fathers, Second Series, vol. 7, trans. C. G. Brown \& J. E. Swallow. New York: Christian Literature Company, pp. 203-434.

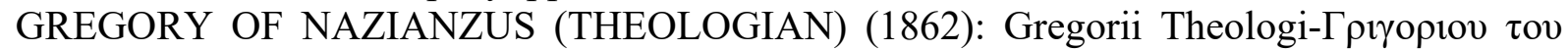

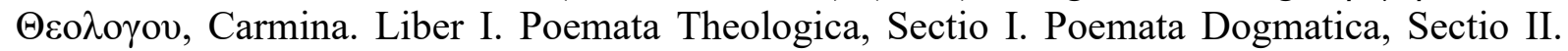
Carmina Moralia, Liber II, Sectio I, Poemata De Seipso, In: Patrologiae Cursus Completus, J. P. Migne, 37, Paris.

HEIBERG, J. L. (ed.) (1929): Anonymi Logica et Quadrivius, cum Scholiis Antiquis. København: L. Bogtrykkeri.

LeCLERQ, J. (1960): The love for learning and the desire for god, trans. C. Misrahi. New York: Fordham University Press.

METZINGER, T. K. (2018): Why is virtual reality interesting for philosophers? In: Frontiers in Robotics and AI. 13th September, 2018, [online] [Retrieved 19/08/2020] Available at: https://doi.org/10.3389/frobt.2018.00101,

MCGUCKIN, J. A. (2006): Gregory: The rhetorician as poet. In: J. Børtnes \& T. Hägg (eds.): Gregory of Nazianzus: Images and reflections. Copenhagen: Museum Tusculanum Press, pp. 193-212.

NORRIS, F. W. (2006): Gregory contemplating the beautiful: Knowing human misery and divine mystery through and being persuaded by images. In: J. Børtnes \& T. Hägg (eds.): 
Gregory of Nazianzus: Images and Reflections. Copenhagen: Museum Tusculanum Press, pp. 19-37.

PAPAIOANNOU, S. (2011): Michael Psellos on friendship and Love- erotic discourse in eleventh- century Constantinople: Early medieval Europe. Oxford: Blackwell.

PLANTINGA, A. (1980): Does God have a nature? Milwaukee: Marquette University Press.

POINCARÉ, H. (1917): La Science et l, Hypothèse, [Science and hypothesis]. Paris:

Bibliothéque de Philosophie Scientifique.

REPETTO, C. \& RIVA, G. (2011): From virtual reality to interreality, in the treatment of anxiety disorders. In: Neuropsychiatry, 1(1), pp. 31-43.

RICOEUR, P. (2004): Memory, history, forgetting. Chicago: University of Chicago Press.

WHITWORTH, B. (2007): The physical world as a virtual reality. In: CDMTS Research

reports, [online] [Retrieved August 10, 2020] Available at:

https://arxiv.org/ftp/arxiv/papers/0801/0801.0337.pdf 